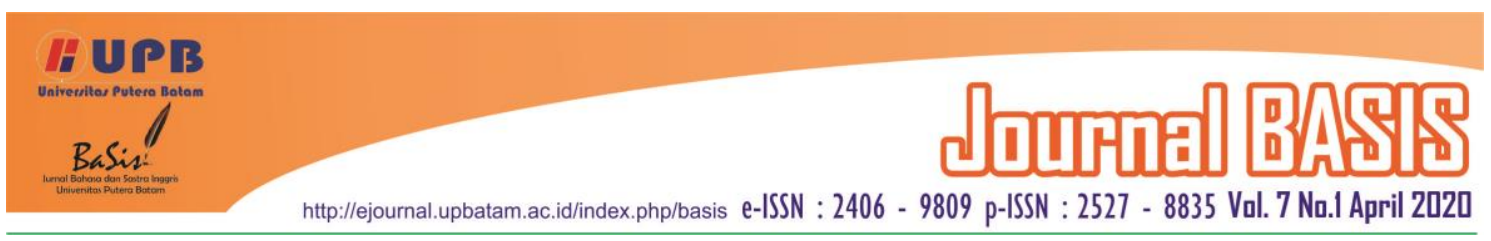

\title{
LEARNING EXPERIENCES USING BLENDED LEARNING ON EFL LEARNERS AT SULAWESI BARAT UNIVERSITY
}

\author{
Putu Wahyu Sudewi \\ Universitas Sulawesi Barat (UNSULBAR), Sulawesi Barat, Indonesia \\ putuwahyu.sudewi@unsulbar.ac.id
}

\begin{abstract}
Blended learning is a mixed learning model between conventional learning or commonly called face-toface and e-learning. This learning model utilizes an internet connection to do one of its components, namely online learning that utilizes certain applications. Based on that, the problems examined in this study are: (1) How did students feel about their blended learning experience, (2) What difficulties/challenges did students experience during their blended learning experience? This study aims to determine learning experiences and difficulties/challenges using blended learning models in EFL learners at the University of Sulawesi Barat and the type of ethnographic research that focuses on case studies. This study focuses on case studies in order to investigate deep phenomena regarding a case. Data are described descriptively. The subjects in this study are students or learners of English as a foreign language (EFL) at the University of Sulawesi Barat. Data collection methods are observation, interviews, and questionnaires addressed to EFL students. The validity of the data technique is the technique of triangulation. The result of this study represents 5 learning experiences that faced by all subjects. There were blended learning method made them more excited because can done everywhere, less embarrassing felt, flexible, motivate to active in learning, simplify and speed up the process of nonstop communication. Furthermore, difficulties/challenges faced by all subjects using the method was network connection an Four varying categories emerged and these included: managing time, technical issues, novelty of the learning experience, and learning style.
\end{abstract}

Keywords: Learning Experiences, Blended Learning, EFL Learners

\section{INTRODUCTION}

Lecturers are required to be able to provide optimal learning by using various methods and learning models that are tailored to the characteristics of students. According Benny A. Pribadi (2009) the application of learning system design aims to create successful learning, namely learning that can help students achieve the competencies they want. Therefore, the selection and application of learning model design is one of the critical success factors in mastering student competencies. Learning is an activity that is inseparable from human life.
Experience is a process that occurs and events experienced by someone in his life that occur at a time. Learning experiences are the processes and activities carried out by each individual student in a special class (classroom) in accordance with the learning method or strategy provided by each educator. Each lecturer has a different teaching strategy in each subject so that this can fill students' learning experience. Learning experience is closely related to the development of process skills. The more active students intellectually, manually and socially, the more meaningful the students' learning 
experiences are. According to Tyler cited in Spriadi (2015), learning experience is not the same as the content of learning materials or activities carried out by the teacher. The term learning experience refers to the interaction between the learner and the external conditions in the environment he reacts to. Learning, through active student behavior; what he does when he studies, not what the teacher does.

The development of information technology today is inevitable its influence on the world of education. The development of information technology and this communication has an impact on the use of teaching aids such as computers and the internet, for example E-learning. Elearning is a learning process electronically. But learning is not merely technology, because learning is essentially more about the process of interaction between teacher, student, and source study. Although E-learning can be used independently by students, its existence the educators become very meaningful as an adult whose function is to provide support and assist students in the learning process. In other words, face to face process becomes important and should not be abandoned in learning. So by combining E-learning and face-to-face learning enable the achievement of effective learning. This learning is called blended learning.

Blended learning is a type of learning combining classical teaching (face to face) with online teaching (Sari, 2013). Blended learning in this study is considered as face to face learning interaction with an online approach. Online learning inside this research was conducted with the Edmodo application. Edmodo is a social network for learning based learning management system (LMS). Edmodo gives facilities for teachers or lecturers, students a safe place to communicate, collaborate, share learning content and applications, homework for students, class discussions virtual, online tests, value provision, and so on. Edmodo is very comprehensive as a course management system like Moodle, the difference is that accesses is faster and easier use it. Edmodo has three functions in the learning process, namely function substitute, companion, and complement. Based on the pre-observation in the English education department students batch of 2018, the researcher found the students would like learn use blended learning in listening course because learning process will be more effective because of the usual teaching and learning process carried out (conventional) will be assisted with elearning which in this case standing on information technology infrastructure and can be done anytime and anywhere. Learning has used ICT that is relevant to present and future life based on that, the researcher conducted a present study about learning experiences of students in English Education Department students' batch of 2018 at Sulawesi Barat University.

\section{LITERATURE REVIEW}

\subsection{Learning Experience}

Different country means different culture. Culture is defined as the ways of beliefs; aesthetic standard, behavioral norms, values, and style of communication which the society has develop to survive in human environment (Pusch, as cited in Wan, G, 1999). Furthermore, culture in academic life between other countries also different. According to Bennett (as cited in Wan, G, 1999) the students from different country or culture learn in different ways, and that they differ in self-expression, communication style, and cognitive styles. The different cultures also make the different system of education in which make the different 
way in learning. In line with the statement, Pusch (as cited in Wan, G. 1999) stated that learning process could run starting with ethnocentrism at particular case end of the range to exactly structure for adjustment. Furthermore, Briggs (as cited in Wan, G. 1999) also stated that when individuals encounter another social environment, they are liable with knowledge clash between their social predispositions and the values, beliefs, and conclusions of the host society. The learning process also not only influenced by the culture but also the motivation and power relationship between the students to their teacher or lecturers. In addition, because of the different culture, they can have positive or negative experience during the learning process. According to oxford dictionary, experience means practical contact with and observation of facts or events. So based on the theories above, it can be conclude that, different culture means different ways of studying, communication style, and cognitive style. The English foreign language learners had their own experience on the learning process when study foreign language. Learning experience means contact with the events in the learning process.

This is related with Tyler cited Lestari (2011) explain that learning experience is not the same as the content of learning materials or activities carried out by the teacher. The term learning experience refers to the interaction between the learner and the external conditions in the environment. Caswel and Campbell (in Lestari, 2011) argued that the curriculum to be composed of all the experiences of children has under the guidance of teachers. Based on this opinion it can be explained that learning experience refers to learning through active student behavior. Learning will be owned by students after he follows certain teaching and learning activities.
There are various efforts made by the teacher in his efforts to guide students to have certain learning experiences.

\subsection{Blended Learning}

Blended learning is a term derived from the English language, which consists of two syllables, blended and learning. Blend means a blend which means there are a wide variety of teaching methods are used. Learning means learning. So it can be interpreted as merging or blending aspects of learning. Blended learning can consist of two or more strategies or media that can be used by teachers. Blended learning is learning that combines technology and information-based learning (computer media) with classroom based learning or face to face. Aspects that can be combined in the form of methods, media, resources, learning strategies and not only combines face to face and online learning (e-learning) course. Thus it can be said blended learning is a learning method that combines two or more learning methods and approaches to achieve the objectives of the learning process.

According to Tucker (2003), blended learning is a formal education program in which a student is engaged in active learning in part online where they have some control over the time, place, and pace and in part at a brick and mortar location away from home. According to Ward and LaBranche (2003), the blended learning approach seems to be most applicable to learning that is focused on a single topic, or closely related topics. Areas that require indepth study that are hard to synthesize and master in a time limited conference are also good candidates for blended learning. Blended learning is also better oriented to how adults learn. Davis and Fill on Jefferies (2010) state blended learning the combination of traditional face-to-face teaching methods with authentic online learning activities, which 
has the potential to transform studentlearning experiences and outcomes. Based on the description above it can be concluded that blended learning is learning that combines technology and information based learning (computer media) with classroom based learning (face to face) in which students learn to control the time, place and capabilities.

\subsection{Previous Study}

There are many researches that contributed in developing ideas in this research. Fist journal written by (Fatih Saltan, 2016) has conducted study entitled Blended Learning Experience of Students Participating Pedagogical Formation Program: Advantages and Limitation of Blended Education. This study was to investigate the learning experience of students studying pedagogic formation in blended design with regard to attendance, selfconfidence, and attitudes toward both Pedagogic Formation Program (PFP) and the teaching profession. Overall, the results indicated that blended PFP was highly promising regarding professional development, self-confidence, accessibility and eliminating some disadvantages of distance education. Specifically, inherent problems of online education continued to take place in blended design but a balanced blended approach could minimize these weaknesses. Participants indicated that face-to-face sections were more applied, authentic and effective than the online part. On the other hand, most of the participants preferred to attend the online lessons regularly. It was mainly because of availability concerns, travelling, and comfort of their home.

Moussa, Jase (2017) founds three categories students' feelings towards a blended learning class emerged in their research, namely; F2F Preference, Blended Preference, and Converted Preference. The results of the research showed that majority of the students' preferred F2F classes instead of the blended classes. A significant finding of this study was that despite a high percentage of students who preferred a F2F learning experience almost all the students mentioned that they enjoyed the blended learning experience and would either take another blended course or recommend the same course to a friend. Educational implications and future research direction are also discussed.

Medina (2018) has conducted study entitled Blended learning: Deficits and prospects in higher education. The study examines the nature and evolution of the term blended learning (BL), which encompasses numerous connotations, including its conception as a strategy, delivery mode, opportunity, educational shift, or pedagogical approach. Although much has been said in this field, very few studies examine the different types of blends behind their implementation. To address this gap in the literature, the study indicates types of blends and analyses the characteristics of blended learning, its benefits and limitations, supported by a review of literature, and an analysis of a sample of blended learning cases in higher education language-teaching worldwide. The study closes with an examination of different levels of blending, the various perspectives within the educational community on its use, and a discussion of its future applicability, especially in higher education.

\section{RESEARCH METHOD}

\subsection{Research Design}

The focus in this study was on students learning experiences using blended learning on English Education Department batch of 2018. Furthermore, this study was conducted using qualitative approach. Qualitative research is the appropriate research when the researcher doesn't know the 
variables and need to explore (Creswell, 2012). In addition, there might be limitation of literature review in this study and need to be explored by the researcher itself. Case studies as an empirical process of searching for knowledge to investigate and examine various phenomena in real life contexts. The case study approach can be applied if the boundary between phenomena and real life contexts is visible or not clearly visible and there are various sources that can be used as evidence references and information gathering.

According to Creswell (2012), a case study is a research that explores a system that is bound or a case (or may be a number of cases) that occurs during a certain period of time through the collection of in-depth and detailed data from various sources of information that can be trusted to testify. Information gathering in the case study according to Creswell can be done by conducting interviews with informants, direct field observations, as well as various documents and pre-existing reports and materials in the form of audiovisual material.

The "case" represents a single individual, several individuals separately or in a group, and series process of students' activities. It is focusing on developing an in-depth understanding of a case, such as an event, activity, or process that often includes the study of an individual or several individuals, such as students or teachers. It is a case analysis of a person, event, activity, or process which is analyzed by a cultural perspective. Therefore, the researcher will choose case study design as the design of this study.

In this study, the data were taken from observation, interview, and questionnaire in order to gain information and data. The researcher found out information in written form and later on analyzed and explained descriptively. be supported by references so that the explanation can be accepted scientifically.

\subsection{Setting of the Study}

The setting of place of this study is EFL learner in Sulawesi Barat University. Specifically, this study was conducted at the English Education Department class who will be English teacher in the future. The site has been chosen purposively for several reasons. One of the reasons is that the university is considered as the favorite campus and state university in Majene regency. It can be seen from the students who study there not only do they come from Majene regency or Sulawesi Barat province but also from other province. The second reason is that the students who enter in this university have already passed the test selection before.

\subsection{Subjects of the Study}

The subject of this study is English education department students batch of 2018. There were four class of the batch. The researcher was conducted the research just into one class. In this study, the researcher was conducted observation, question, and interview in order to collect the data. Furthermore, the researcher observed their learning process in the class. Thus activity did in order to collect the data about learning experience using blended learning in EFL Learner.

\subsection{Object of the Study}

The object of this study is the learning experiences using blended learning in EFL learner at Sulawesi Barat University. This study was conducted because of a phenomenon about the learning experiences using blended learning was interesting and significant to be described and analyzed in which the learning experience will be 
investigated by using the theories stated in review related literature.

\subsection{Instruments of the Study}

In this study, the researcher was the main instrument that used interview guide and questionnaire as device to collect the data. The researcher played the main role of the study in the process of collecting the data until the data are saturated.

\subsection{Procedure of Data Collection}

There were four procedures in order to collect the data for this study, such as preliminary observation, further observation, conducting interview, and giving questionnaire.

\subsection{Data Analysis}

The data analysis of this study was based on Miles and Huberman (1994), there are three types of data analysis, such as data reduction, data display, and conclusion drawing verification. The researcher analyzed the data continuously until the data could answer the statements of problems of this research.

\subsection{Data Reduction}

The data were obtained through transcription and questionnaire. When the data were very large, the researcher reduced the unimportant information to be described. Furthermore, the researcher identified the talk that was related to statements' of problem in this study. The data were used to know the students learning experiences using blended learning.

\subsection{Data Display}

In this study, the display showed in form of written text. The transcription and the questionnaire were described descriptively using the researcher's words. The data of questionnaire and interview are in the form of table below:
Table 3.1. The Data Display of

Students Feel and

Difficulties/Challenges about Their

Blended Learning Experiences

(Questionnaire)

(Rate from "1" poor to "5" excellent)

\begin{tabular}{lccccc}
\hline Statement & 1 & 2 & 3 & 4 & 5 \\
\hline & & & & & \\
& & & & & \\
& & & & \\
\hline
\end{tabular}

Table 3.2. The Data Display of Students Feel about Their Blended Learning Experiences (Interview)

Learning Experiences

Student 1

Student 2

Student 3

Table 3.3. The Data Display of Students Difficulties/Challenges toward Their Blended Learning Experiences (Interview)

\begin{tabular}{l}
\hline Difficulties/Challenges \\
\hline Student 1 \\
Student 2 \\
Student 3 \\
\hline
\end{tabular}

\subsection{Conclusion Drawing/ Verifying}

In this study, the researcher drew conclusion of the study based on the findings of data that have been collected before. In drawing the conclusion, the researcher considered the problems of the study on students learning experiences using blended learning in English education department batch of 2018. In order to obtain reliable and valid data as the result of this study, the researcher used triangulation technique. In this study, the researcher did crosschecked the data from observation, interview, and questionnaire. 


\section{RESULT AND DISCUSSION}

Implementation of blended learning in listening for professional purposes courses began from semester three in the academic year 2019/2020. Study loaded students must take in following two credits for one semester. Implementation blended learning in listening for professional purposes subjects, lectures carried out by combining conventional learning (face to face) and online learning. Blended learning model in English education department actually very good because besides the lecturer concerned understands about learning system using edmodo in e-learning where part of the blended learning component is. By using this learning researchers saw that students really enjoy learning listening for professional purposes during class hours. The purpose of developing blended learning was combining the best features of classroom learning (face to face) with the best features of online learning to enhance independent learning actively by students and reduce the amount of time face to face in class.

In accordance with the concept of the theory that blended learning should be able overcome deficiencies in pure face-to-face learning and e-learning pure. There were many benefits taken from the combined learning model between students is not only focused on the material provided in the classroom, but with the use of e-learning that uses edmodo. Students could download the material or just red it online material that the lecturer had uploaded in the virtual class. So students could read directly through a smartphone or can also be printed. As we know that the times changed the way students learn. Learning was more varied so students could choose to use what kind of ways to read the material needed. Other advantages of it lecturers could control the students activities and between participants students share file material, cannot be glued to remote discussions with same place.

\subsection{Students Responses on Blended Learning Experiences}

The data were collected through questionnaire consisting of students response to blended learning method. The data presented based on the observed aspects. The first question were asked about "what blended learning is?". "Blended learning is one of the methods that is used in learning. This method was combining between learning in face to face and e-learning (online)". (Subject 2, interview 11 December 2019). Subject 14 gave opinion, "as far as I am concerned, blended learning is a learning method that combines two learning patterns. That is learning in the classroom or face to face and e-learning which use certain media". Based on EFL learners' opinion, it can be stated that students define blended learning as learning done online and face to face, both in the form of access to learning material, task collection and discussion. Students give positive responses to implementation of blended learning. A recapitulation of the experience gained by students using blended learning is presented in the table below:

Table 4.1. Examples of Students Responses on Blended Learning Experiences

I really like this learning method, because I can be more active to give my respond, whether it's face to face learning or e-learning.

Felt great relief because the programmed does not require physical presence

Blended learning provides me with sufficient flexibility in my studies.

My lecturer and I can continue the discussion in the classroom chat. So when the material has not been completed during a face-to-face meeting it can be finished in the realm of chat.

Can repeat at any time to repeat the material provided by the lecturer.

I can see teaching materials are very useful for me for those who are not present or unable to 
attend face-to-face meetings.

Quiet students can be free to say and think without fear of embarrassment, while the active type of students can pose questions at any time as long as they are connected to the internet.

I think blended learning model will motivate me to be active in learning, because blended learning model can be done anytime and anywhere, so it will be easier for me or other students to do learning process, and in my opinion, blended learning is a fun learning method, so we will be more active in learning.

Based on student's opinion on table 4.1, students like blended learning model where learning used face to face and e-learning where access to learning materials, task collection and discussion was done online. This opinion was in accordance with the definition of blended learning according to Hamid cited in Norlin and Travis (2008) which states in e-learning between teach providers (educators) and students (students) separated by cyberspace.
Learning resources or teaching materials can support students' readiness in the learning process. Learning resources were presented in the form of audio and websites that are tailored to the material to be delivered resulting in students being able to repeat the material that has been learned every time.

\subsection{Student's Difficulties/Challenges toward Their Blended Learning Experience}

There

was difficulties/challenges were identified and these can be seen in table 4.2 below. Four varying categories emerged and these included: managing time, technical issues, novelty of the learning experience, and learning style.

Table 4.2. Student's Difficulties/Challenges Towards Their Blended Learning Experiences

Category Item Sample Responses of $\quad$ Sample Pictures Using Edmodo
interview

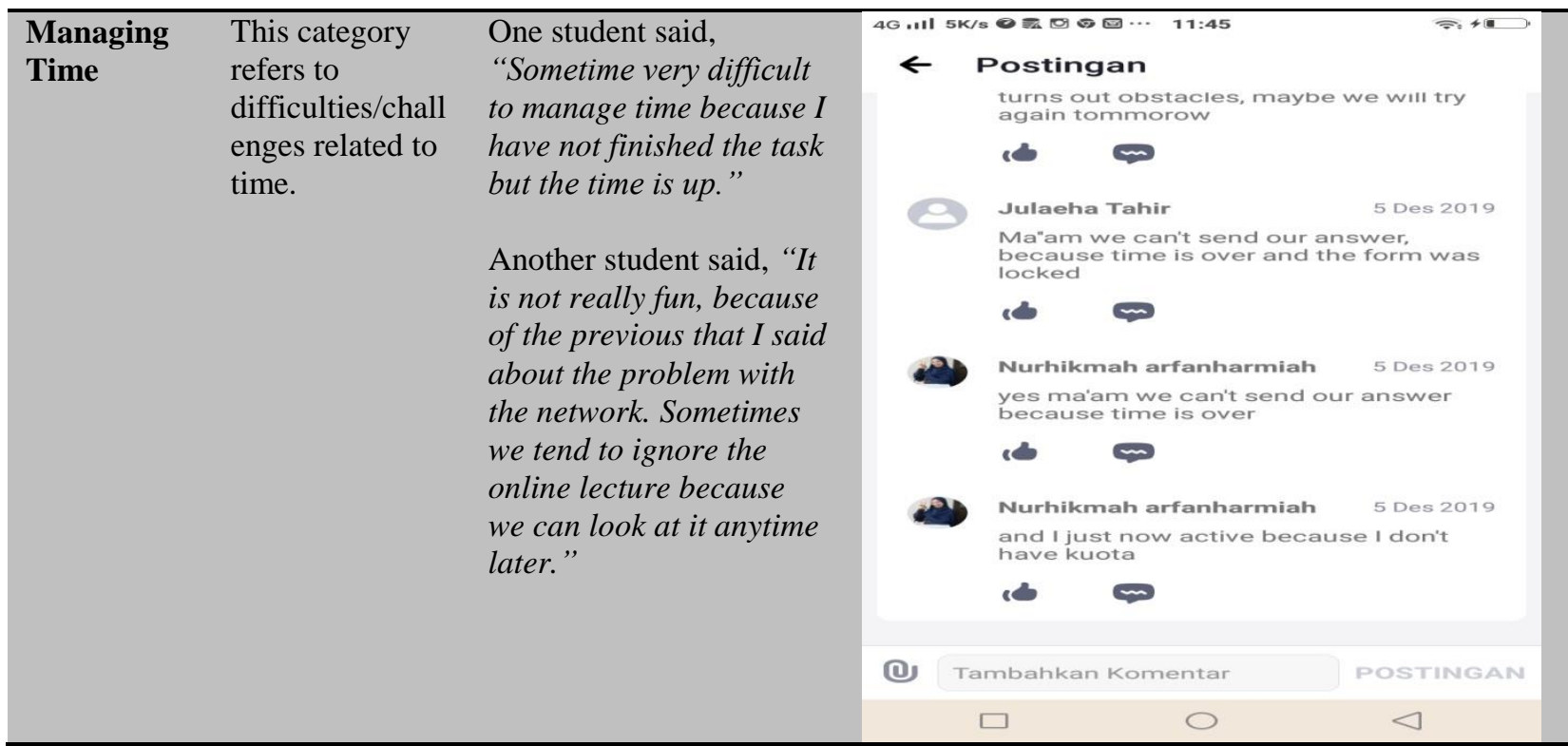




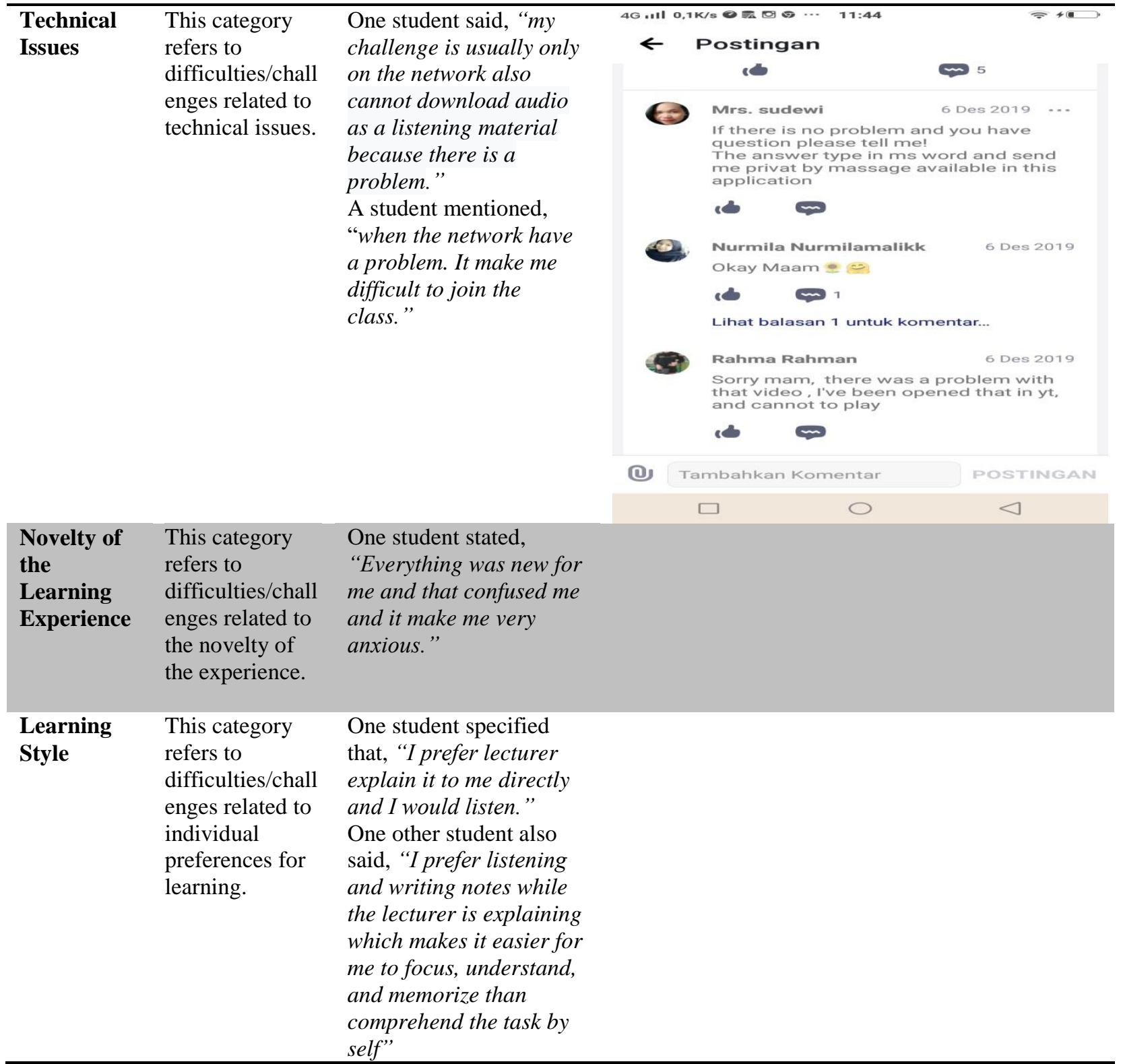

On interviews with informants, the results of interviews and observations directly indeed conical to connections and devices those were still limited. This was a vital subject when discussing the model blended learning because this model really needs smooth internet connection, so online learning takes place as you wish. The blended learning component consists of conventional learning and e-learning, in this case the focus may be an obstacle in the elearning component where internet connection is a major obstacle in the learning process. According to the result of observations that researchers do conventional learning does not seem to have a constraint means, because the facilities and infrastructure in the class could be considered complete. Lecturer was able to use the tools available in the classroom to support conventional learning. Actually largest portion in this learning is conventional and for online learning only as a complement to learning support. Based on the results of the data that researchers got by combining interview data, the following was an expression of the student's solution to the effort as follows: "If we 
have a quota problem, we can go to friends to borrow cell phones to charge edmodo, if Wi-Fi can be found in some places that don't need Wi-Fi password"(Interview 11 Desember 2019).

Based on the students varied opinion, students' opinions were focused on buying data packages or utilizing internet cafes for just working on the quiz. There were some students who haven't done it because class time is up and lecturers assign quizzes to be done at their homes. The researchers felt the problem of internet packages may already be a primary need of each student because they must charge their quota to play social media they have, learning used internet the researcher think must be consistent and not half so the results will obtain optimally in accordance with the wishes.

\section{CONCLUSION}

In conclusion, this study was conducted for three months in the EED students at Sulawesi Barat University. Based on the data, the researcher found that there were 5 learning experiences that faced by all subjects. There were blended learning method made them more excited because can be done everywhere, less embarrassing felt, flexible, motivate to be active in learning, simplify and speed up the process of nonstop communication. Furthermore, difficulties/challenges that were faced by all subjects using the method was network connection. The portion of independent learning using the web has the same composition as the face to face process. Blended learning is mainly focused on students. Students must be independent at certain time and responsible for their learning.

\section{REFERENCES}

Creswell, J. W. (2012). Educational Research: Planning, Conducting, and Evaluating Quantitative and Qualitative Research. United States of America: Pearson Education

Hamid, A. A. (2001). e-Learning: Is it the "e" or the learning that matters? The Internet and Higher Education, 4(3-4), 311-316. https://doi.org/10.1016/S10967516(01)00072-0

Jefferies, Amanda Lucille Joanne. (2010) Blended Learning: Undergraduate Students' Experiences of Using Technology To Support Their Learning. Thesis. United Kingdom: University of Hertfordshire.

Ko, Susan and Rossen, Steve. (2004). Teaching Online a Practical Guide, Second Edition, New York: Houghton Mifflin Compeny.

Krasnova, Tatiana and Sidorenka, Tatiana. (2013). Blended Learning in Teaching Foreign Language, ICT for Language Learning 6th Edition.

Lestari, Puji. (2011). Pengalaman Pembelajaran. retrieved November 29, 2019. http://srisukopujilestari.blogspot. com/2011/07/pengalamanpembelajaran.html

Li, Zhingan. et al, (2014). Switching to Blended Learning: The Impact on Students Academic Performance, Journal of Nursing Education and Practice, 4(3), 245-251.

http://www.sciedu.ca/journal/ind ex.php/jnep/article/view/3477 
Mason, Robbin and Rennie, Frank. (2006). E-learning The key Concept, New York:

Routladge Tylor \& Francis Group.

Medina, Liliana Cuesta. (2018). Blended Learning: Deficits and Prospects in Higher Education.

Australasian Journal of Educational Technology, 34(1), 42-56.

https://doi.org/10.14742/ajet.310 0

Miles, M.B. \&Huberman, A.M. (1994).Qualitative Data Analysis: An Expanded Sourcebook. London: Sage Publication.

Moussa, Jaze. (2017). Student Experiences of a Blended Learning Environment. International Journal of Learning, Teaching and Educational Research. 16(9), 6072. https://www.ijlter.org/index.php/ ijlter/article/view/993

Norlin and Travis. (2008). E-Learning and Business Plans, United States of America: Scarecrow Press

Peribadi, A. Benny. (2009). Model Desain Sistem Pembelajaran. Jakarta: Dian Rakyat.

Sari, Annisa. (2013). Strategi Blended Learning Untuk Peningkatan Ke mandirianBelajar Dan Kemamp uan CriticalThinking Mahasiswa di Era Digital. JurnalPendidikan Akuntansi Indonesia, 11(2), 3243. https://journal.uny.ac.id/index.ph p/jpakun/article/view/1689

S. Alya, Jesica. (2009). Blended Learning as New Approach to Social Work Education, Journal of Social Work Education, 45(2), 277-288. https://doi.org/10.5175/JSWE.20 09.200700112

Saltan, Fatin. (2017). Blended Learning Experience of Students Participating Pedagogical Formation Program: Advantages and Limitation of Blended Education. International Journal of Higher Education, 6(1), 6373.

https://doi.org/10.5430/ijhe.v6n1 p63.

Sharma, Pete. (2011). Key Concept in ELT Blended Learning, ELT Journal, 64(4), 456-458. https://doi.org/10.1093/elt/ccq04 3

Spriadi. (2015). Pengembangan Kurikulum Model Tyler. Retrieved November 29, 2019 from http://dspriadi333.blogspot.com/ 2015/10/pengembangankurikulum-model-tyler.html

Tucker, Catlin; Umphrey, Jan. (2013). Blended Learning. Akademic Journal. 14(1), 36-41. https://eric.ed.gov/?id=EJ101854 0

Ward, Jeff; LaBranche, Gary A. (2003). Blended learning: The convergence of e-learning and meetings. Vol. 35. Ed. 4.United State: International Franchise Association. 
Wan, G. (1999). The learning experience of Chinese students in American universities: A crosscultural perspective. 